\title{
Quality of nursing care on Patients with Tracheostomy
}

\author{
Dr. Shereen Ahmed Qalawa1 Dr. Adel El-Hady Diab2 Dr. Samia Eaid El- Gazzar3, \\ Hala Mossad El-Gawab \\ Assistant professor of medical -Surgical department, Faculty of Nursing, Port- said \\ University, Assistant professor of Anesthesiology and intensive care department, \\ Faculty of Medicine, Al-Azhar University in Damietta city, Lecturer of Medical \\ Surgical Nursing, Faculty of Nursing, Port- said University, Clinical instructor at \\ Technical Institute of Nursing, al-Azher University in Damietta city.
}

\begin{abstract}
Background: Tracheostomy is a surgical creation of a stoma at the skin surface which leads to the trachea. It is indicated for upper airway obstruction which may be caused by laryngeal edema resulting from inhalation burns injury, anaphylaxis, trauma or infection. It is also indicated for prolonged ventilation, to protect the airway in conditions with excessive tracheobronchial secretions that require regular suction and used as part of another procedure e.g. head and neck surgery. Aim of the study: to determinethe qualityof nursing care on Patients with Tracheostomy. Design:A descriptive research design was utilized in this study. Setting: The study was conducted in the Intensive Care Unit at El- azhar university hospital.Sample:The study data was collected from all available nurses (30 males and females) worked in the Intensive Care Unit in the time of data collection and all tracheostomiezed patients admitted to Elazhar university hospital in period of 6 months. (50 patients). Results: more than three quarters of the studied nurses were aged from 20 to less than 30 years. One third of the studied nurses had years of experience less than 5 years. More than two thirty of nurses had satisfied level of knowledge about tracheostomy care. There were more than two thirty of nurses had satisfied level of total practice. There is statistically significant relation between total nurse's knowledge and nurse's practice. There is highly statistically significant positive correlation between total nurse's knowledge and total nurse's practice. CONCLUSION: The most common cause of performing tracheostomy was needing artificial ventilation more than 15 days. Most of the studied nurses had satisfactory level of knowledge and practice regarding providing care to tracheostomy patient There was a statistically significant positive correlation between total nurse's knowledge scores and their total practice scores Recommendations: improved nurses' theoretical knowledge, clinical performance and continuous evaluation of nurse's knowledge and practice are essential to identify nurses' needs and design heath teaching programs according their needs.
\end{abstract}

Key words: Quality, Nursing care, tracheostomy patient. 


\section{INTRODUCTION}

Tracheostomy is one of the oldest surgical procedures recorded in human history. Tracheostomy is a surgical creation of a stoma at the skin surface which leads to the trachea. It is indicated for upper airway obstruction which may be caused by laryngeal edema resulting from inhalation burns injury, anaphylaxis, trauma or infection. It is also indicated for prolonged ventilation, to protect the airway in conditions with excessive tracheobronchial secretions that require regular suction and used as part of another procedure e.g. head and neck surgery (Bhandary and Niranjan, 2011).

Early tracheostomy will speed up the weaning from mechanical ventilation. As a general rule though, endotracheal intubation is the treatment of choice and can be continued for 7-10 days with minimal risk. If it appears that assisted ventilation will be required for longer than 14 days, an elective tracheostomy should be performed. 13 those patients who may possibly be extubated before this time may be assessed on a daily basis until such time as it becomes apparent which option is correct. No patient should be intubated for longer than three weeks however, as the incidence of laryngeal stenosis becomes unacceptably high (Nemati et al., 2013).

In intensive care the placement of a tracheostomy has many benefits including better tolerance of the tube compared with an orotracheal tube, coupled with the need for less sedative and analgesic drug (McGrath\& Thomas, 2011).

Performing a tracheostomy is considered a safe procedure with a low complication rate. The increase in number of tracheostomies performed in the ICU is partly attributed to a belief that early tracheostomy may improve survival; however there is still controversy over the risks and benefits of tracheostomy insertion in critical care patients (McGrath \& Thomas, 2011).

Historically tracheostomies were used to remedy upper airway obstruction, to avoid any laryngeal complications of prolonged tracheal intubation and the continued need for the protection and maintenance of the airway in patients with severe neurological injury, however it is now regarded as beneficial for a subset of the general critical care population, and will often be planned and result from the perceived need for a (relatively) long-term artificial airway (American Association of Respiratory Care, 2010).

The highest priority before performing a tracheostomy is securing the airway. Endotracheal intubation is the most common way of securing the airway while a more permanent airway is achieved by performing a tracheostomy (Nora et al., 2014).

Quality of care provided, thus enhancing the quality of work for doing care is the most important factor which can be accelerated patient's recovery. Some part of the problems with the tracheotomy and substandard and inadequate care can be due to improper implementation of nurses and other part of the physicians and these harmful 
events are due to reception of health and medical care which leads to death and injuries which can be prevented by standard methods (NCEPOD.,2014).

So, the nurses have a vital role in sustaining and improving health care and they are the main foundation of improvement process of the care quality which is very fruitful in achieving the goals of care (Mosazade et al., 2013).

Although, it is possible the employees are given several guidelines to improve the quality of tracheostomy care as the guide in tracheostomy care but some employees of these units may have inadequate required skills and knowledge in the care of these patients. Researches related to quality of care and following up of adult patients undergoing tracheostomy who have been transferred to the public unit are very limited and even the complications related to the illness and even their death is still high (Nemati et al., 2013).

\section{Significant of the study:}

Tracheostomy especially on long-term basis, is associated with significant morbidity. Majority of patients experience tracheostomy related problems during cannulation and /or after decannulation. A large proportion of these problems are however preventable or may be minimized through effective tracheostomy care practices and individualized clinical monitoring of patients (Frcpch et al, 2014).

Thus, this study focuses on risks for early complications of tracheostomy. Since a large number of tracheostomy patients experience problems with the procedure. So, to establish any short comings, this will facilitate assessment of tracheostomy care practices which will go a long way in determining the challenges faced by the patients and also the institutional contributions towards any shortcomings in the quality of care.

\section{AIM OF THE STUDY:}

The aim of present study is todetermine the quality of nursing care on tracheostomy patient.

\section{Objectives:}

1. Assess the quality of nursing care for tracheostomy patient.

2. Assess the factors that influence the care for patients with tracheostomy.

\section{Research question}

1- What isthe quality of nursing care for tracheostomy patient?

2- What is the factors that influence the care for patients with tracheostomy.

\section{Operational definition}

Quality of nursing care refers to procedures or medications which are primarily aimed to providing comfort to a patient or alleviating the person's pain, symptoms or distress, and includes the offer of oral nutrition and hydration. 


\section{SUBJECTS AND METHOD:-}

\section{Research Design:}

A descriptive research design was for the conduction of this study.

\section{Study Setting:}

The study was conducted in the Intensive Care Unit at El- azhar university hospital in Damietta New city.

\section{Study Subjects:}

The study data was collected from all available nurses (males and females) worked in the Intensive Care Unit in the time of data collection $(n=30)$, and all tracheostomiezed patients admitted to El- azhar university hospital in period of 6 months $(n=50)$.

\section{Tools for data collection:}

Tree tools were used to collect data of the presents study as follows:

Tool I: interview questionnaire tool: it was adopted from (Ali, 2013) and adapted based on reviewing recent related literature (Bhandary and Niranjan, 2011) to assess knowledge of nurses regarding tracheostomy care. It includes three main parts as follows:

\section{Part I: Socio-demographic data sheet:}

This part includes 6 items related to demographic data as (name, age, education, years of experience, sex, attended training courses regarding tracheostomy and its nursing care).

\section{Part II: Nurses' Knowledge Questionnaire Sheet:}

This questionnaire Included (17) true or fouls and (17) Multiple Choice Question to assess nurses' knowledge about tracheostomy patient care

\section{Tool II:Nurses's practice sheet:}

It was adapted from (Ramont and Niedringhauf, 2011)it included observational checklist to assess the nurse's practice regarding tracheostomy tube care and tracheobronchial suctioning .

\section{Scoring System:}

Regarding the scoring system for nurse's knowledge, all knowledge variables were weighted according to the item included in the answer of each question. This part (Part II) was corrected from 68 degrees. All questions was measured and divided by the number of questions to obtain the mean knowledge of each nurse. Regarding the scoring system for practicing of the studied nurses, a check list was assigned to score according to its number of sub item. The answer was represented as it is reported in the answer sheet (complete done, uncompleted done, not done). (2) if complete done, (1) score if uncompleted done and (zero) score if not done. The scoring system of the tool checklist was computed and the sheet received a grade out of 94 points. Score below $60 \%$ was considered unsatisfactory while those equal to or above $60 \%$ was considered satisfactory (Ali, 2013). 


\section{TOOL III: Patient's Socio-demographic data sheet :}

It was adapted from (Nyansikera, 2012) included 10 items related to demographic data of tracheostomy patients such as: (Name, age, sex, educational degree, job, social status, reasons for tracheostomy, time of tracheostomy and the place where the tracheostomy was performed.

\section{(Ii) Operational Design}

The operational design included preparatory phase, content validity, pilot study and fieldwork.

\section{The Preparatory Phase}

It included reviewing of literatures related to the problem and theoretical knowledge of various aspects of the problem using books, articles, periodicals and magazines to develop tools for data collection.

\section{Content Validity}

The tool was tested for its content validity, comprehensiveness and applicability by 9 expertises of professors and lecturers from the Medical-Surgical Department; Faculty of Nursing, Port Said University and El Mansoura University and from medicine department, Faculty of Medicine, Al-Azhar University who revised the tools and modifications were done according to their opinion.

\section{Pilot Study}

Pilot study was conducted on $10 \%$ of both subjects(nurses and patients). It was done to test the clarity and practicality of the tools, the results of the data obtained from the pilot study helped in modification of the tools; items were corrected or added as needed. Accordingly, modifications were done and the final form was developed. The results from the pilot study were excluded from the main statistical sample.

\section{Reliability of the study tool:}

Cronbach alpha coefficient was used to assess the internal consistency of the tool. Nurse`s knowledge tool was (0.74), Nurse`s practice tool was (0.81).

\section{Field work:}

The data was collected from the beginning of May (2015) to the end of October (2015). The researcher visited Al-Azhar university hospital three days weekly during three shifts (morning, afternoon \& night) to collect the data by using tool I, tool II. The questionnaire sheet was given to nurses individually in the work place; each nurse took about 30-45 minutes to complete the questionnaire sheet. The observation checklist was utilized by the researcher toassess nurse's practice through the three times for each skill, during morning, afternoon \& night shift. The patients' outcome 
assessment sheetwas utilized by the researcher to assess patients' outcome resulting to nursing care at the early stage after tracheostomy operation, it took 24 hour to complete patients outcome assessment sheet.

\section{(III) Administrative design:}

An official permission for data collection was obtained from Al-Azhar University hospitalsfrom the hospital administrative personnel by submission of a formal letter from the vice dean of the Faculty of Nursing in Port Said University. Meeting and discussion were held between the researcher and the nursing administrative personnel to make them aware about aims and objectives of the research, as well as, to get better cooperation during the gathering of the research data.

\section{Ethical Considerations:}

Nurses and patients' consent was obtained before data collection and after explanation of the aim of the study. Anonymity, confidentiality and privacy were asserted. The nurses were informed that his / her participation in the study is voluntary and he/she can withdraw at any time and his/her withdrawal will not affect the care received at the hospital.

\section{Statistical design:}

III. The collected data were catogorized, revised, stored, tabulated and analyzed using number and percentage distribution. Statistical analysis was done by computer using Statistical Package of Social Science program (SPSS) package version 16. Proper statistical tests were used to determine whether there was a significant statistical difference between variables of the study.

\section{RESULT:}

Table (1): Shows that slightly more than three quarters $(76.7 \%)$ of the studied nurses were aged from 20 to less than 30 years and half(50\%) ofthemweretechnical nurse. However one third (33.3\%) of the studied nurses had years of experience less than 5 years. While all of studied nurses were female at Al- azher university hospital.While most of the nurses $(86.7 \%)$ didn't attend any previous training courses. While $13.3 \%$ attended training courses and $(75 \%)$ of them reported that they got benefits from these courses

Table (2): Enumerates that near to two third (66\%) of nurses had satisfied level of knowledge about tracheostomy characteristics, and $(56.7 \%)$ of them know about tracheostomy suction. While, there were near to two third $(61 \%)$ of nurses had satisfied level of total knowledge.

Table (3):Enumerates that near to two third(60\%) of nurses had satisfied level of practice about tracheostomy care and (73.3\%)of them had satisfied level of practice 
about tracheostomy suction. Therefore, there were more than two third(66.7\%) of nurses had satisfied level of total practice.

Figure (1):Shows that more than two third $(66.7 \%)$ of nurses had satisfied level of total practice.

Table (4):Shows that $(60 \%)$ of patients were malewith mean age of $37.04 \pm 1.66$, and $(54.0 \%)$ of them were married. Meanwhile $(30 \%)$ of them were in fifty or more, $(18.0 \%)$ of them were illiterate, $(56.0 \%)$ of them didn't work

Table (5): This table shows that, there is statistically significant positive correlation between total nurse's knowledge and total nurse's practice $(\mathbf{P}=\mathbf{0 . 0 4 5})$.

Table (6): This table reveals that, there is statistically significant relation between the total nurses' practice and their age. Also there is a statistically significant relation between total nurses' practice and their educational level and years of experience $(\mathbf{p}=$ 0.038)

Table (1): Number and percentage distribution of the studied nurses according to their socio-demographic characteristics $(n=30)$.

\begin{tabular}{|l|l|l|}
\hline $\begin{array}{l}\text { Socio-demographic } \\
\text { characteristicsof the studied nurses }\end{array}$ & No & (\%) \\
\hline Age / years: & 1 & 3.3 \\
$<20$ & 23 & 76.7 \\
$20<30$ & 5 & 16.7 \\
$30<40$ & 1 & 3.3 \\
$40-$ & & \\
\hline Education: & 6 & 20.0 \\
diploma nurse & 15 & 50.0 \\
technical nurse & 9 & 30.0 \\
B.Sc. degree & & \\
\hline Experience / years: & 6 & 20.0 \\
$<1$ & 10 & 33.3 \\
1<5 & 5 & 16.7 \\
5<10 & 9 & 30.0 \\
$10-$ & & \\
'Training courses: & 4 & 13.3 \\
Yes & 26 & 86.7 \\
No & & \\
If yes: (n=4) & 1 & 25.0 \\
Little & 3 & $\mathbf{1 0 0}$ \\
Average & $\mathbf{3 0}$ & \\
\hline Total & & \\
\hline & & \\
\hline
\end{tabular}


Table (2): Total nurses`Knowledge regarding tracheostomy $(n=30)$.

\begin{tabular}{|l|c|c|c|c|}
\hline \multirow{2}{*}{$\begin{array}{l}\text { nurses Knowledge regarding } \\
\text { tracheostomy }\end{array}$} & \multicolumn{4}{|c|}{ Total score level } \\
\cline { 2 - 5 } & \multicolumn{2}{|c|}{ Satisfactory } & \multicolumn{2}{c|}{ Unsatisfactory } \\
\cline { 2 - 5 } & No & \multicolumn{2}{|c|}{ No } & $\%$ \\
\hline Knowledge about tracheostomy care & 18 & 60.0 & 12 & 40.0 \\
\hline $\begin{array}{l}\text { Knowledge about tracheostomy } \\
\text { characteristics }\end{array}$ & 20 & 66.7 & 10 & 33.3 \\
\hline $\begin{array}{l}\text { Knowledge about tracheostomy suction } \\
\text { Total knowledge }\end{array}$ & 17 & 56.7 & 13 & 43.3 \\
\hline
\end{tabular}

Table (3): Percentage distribution of the studied nurses according to their total nurses

Practice regarding tracheostomy $(\mathrm{n}=30)$.

\begin{tabular}{|l|c|c|c|l|}
\hline \multirow{2}{*}{$\begin{array}{l}\text { Total Nurses } \\
\text { tracheostomy }\end{array}$} & \multicolumn{4}{|c|}{ Total score level } \\
\cline { 2 - 5 } & \multicolumn{2}{|c|}{ Satisfactory } & \multicolumn{2}{|c|}{$\begin{array}{c}\text { Unsatisfactor } \\
\text { y regarding }\end{array}$} \\
\cline { 2 - 5 } & No & $\%$ & No & $\%$ \\
\hline Practice about tracheostomy care & 18 & 60.0 & 12 & 40.0 \\
\hline Practice about tracheostomy suction & 22 & 73.3 & 8 & 26.7 \\
\hline Total Practice & $\mathbf{2 1}$ & $\mathbf{6 6 . 7}$ & $\mathbf{9}$ & $\mathbf{3 3 . 3}$ \\
\hline
\end{tabular}


Figure 1 : Total nurses` Practice regarding tracheostomy $(\mathrm{n}=30)$.

\section{Total practice}

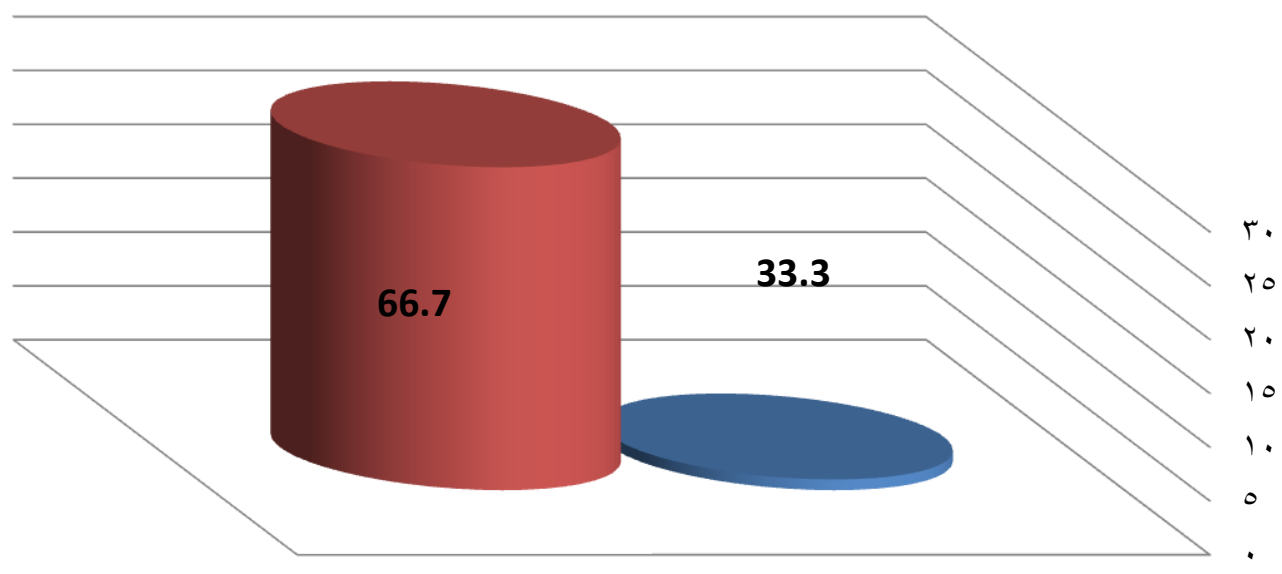

Total Practice

- !REF\#

Table (4): percentage distribution of the patients according to their sociodemographic characteristics $\quad(n=50)$.

\begin{tabular}{|l|l|l|}
\hline $\begin{array}{l}\text { PatientSocio-demographic } \\
\text { characteristics }\end{array}$ & $\begin{array}{l}\text { Frequency } \\
\mathbf{n = 5 0}\end{array}$ & $\begin{array}{l}\text { Percentage } \\
\mathbf{\%}\end{array}$ \\
\hline Age: & 28 & 56.0 \\
14-less than 35 & 15 & 30.0 \\
35- less 55 yrs & 7 & 14.0 \\
55 or more & $37.04 \pm 1.66$ & \\
\hline Mean \pm SD & 30 & 60.0 \\
\hline Gender: & 20 & 40.0 \\
Male & & \\
Female & 9 & 18.0 \\
\hline Education: & 12 & 24.0 \\
illiterate & 19 & 38.0 \\
preparatory & 10 & 20.0 \\
diploma & & \\
bachelor & 22 & 44.0 \\
\hline Occupation: & 28 & 56.0 \\
work & & \\
not work & 27 & 54.0 \\
\hline Social status: & 19 & 38.0 \\
married & 4 & $\mathbf{1 0 0 \%}$ \\
single & $\mathbf{5 0}$ & \\
\hline widow & & \\
\hline Total & & \\
& & \\
\hline
\end{tabular}


Table (5): Correlations between total nurses' knowledge scores and total nurses' practice scores

\begin{tabular}{|l|c|c|}
\hline \multirow{2}{*}{ Total nurses` Practice } & \multicolumn{2}{|c|}{ Total nurses` knowledge } \\
\cline { 2 - 3 } & $\mathbf{r}$ & $\mathbf{p}$ - value \\
\hline & & $\mathbf{. 0 4 5}$ \\
\hline
\end{tabular}

Table (6): Relation between nurses` Practice and factors affecting $(\mathrm{n}=30)$.

\begin{tabular}{|c|c|c|c|c|c|c|}
\hline \multirow{3}{*}{$\begin{array}{c}\text { Relation between nurses } \\
\text { Practice and factors } \\
\text { affecting }\end{array}$} & \multicolumn{4}{|c|}{ Nurses Practice } & \multirow{3}{*}{$\mathbf{X}^{2}$} & \multirow{3}{*}{ p-value } \\
\hline & \multicolumn{2}{|c|}{ Inadequate } & \multicolumn{2}{|c|}{ Adequate } & & \\
\hline & $\mathbf{n}$ & $\%$ & $\mathbf{n}$ & $\%$ & & \\
\hline $\begin{array}{l}\text { Age / years: } \\
>20 \\
20>30 \\
30>40 \\
40-\end{array}$ & $\begin{array}{l}0 \\
8 \\
0 \\
1\end{array}$ & $\begin{array}{l}0.0 \\
88.9 \\
0.0 \\
11.1\end{array}$ & $\begin{array}{l}1 \\
15 \\
5 \\
0\end{array}$ & $\begin{array}{l}4.8 \% \\
71.4 \% \\
23.8 \% \\
0.0\end{array}$ & 5.155 & $.011 *$ \\
\hline $\begin{array}{l}\text { Education: } \\
\text { diploma nurse } \\
\text { technical nurse } \\
\text { B.Sc. degree }\end{array}$ & $\begin{array}{l}0 \\
6 \\
3\end{array}$ & $\begin{array}{l}0.0 \\
66.7 \\
33.3\end{array}$ & $\begin{array}{l}6 \\
9 \\
6\end{array}$ & $\begin{array}{l}28.6 \\
42.9 \\
28.6\end{array}$ & 4.333 & $.019 *$ \\
\hline $\begin{array}{l}\text { Training courses: } \\
\text { Yes } \\
\text { No }\end{array}$ & $\begin{array}{l}2 \\
7\end{array}$ & $\begin{array}{l}22.2 \\
77.8\end{array}$ & $\begin{array}{l}2 \\
19\end{array}$ & $\begin{array}{l}9.5 \\
90.5\end{array}$ & .879 & .348 \\
\hline $\begin{array}{l}\text { Experience / years: } \\
>1 \\
1>5 \\
5>10 \\
10-\end{array}$ & $\begin{array}{l}2 \\
3 \\
0 \\
4\end{array}$ & $\begin{array}{l}22.2 \\
33.3 \\
0.0 \\
44.4\end{array}$ & $\begin{array}{l}4 \\
7 \\
5 \\
5\end{array}$ & $\begin{array}{l}19.0 \\
33.3 \\
23.8 \\
23.8\end{array}$ & 3.069 & $.038 *$ \\
\hline
\end{tabular}

* Statistically significant at $\mathrm{p} \leq 0.05$

\section{DISCUSSION:}

Tracheostomy is a surgical creation of a stoma at the skin surface which leads to the trachea. It is indicated for upper airway obstruction which may be caused by laryngeal edema resulting from inhalation burns injury, anaphylaxis, trauma or infection. It is also indicated for prolonged ventilation. (Bhandary and Niranjan, 2011). 
To provide safe and competent care, nursing staff must understand the immediate postoperative and long-term management of tracheostomy patients. Each institution should have its own standard policies and procedures for caring for these patients. Basic minimal care usually consists of cleaning or changing the inner cannula, caring for the stoma, and suctioning at least 3 times a day. Depending on the thickness and quantity of secretions, more frequent inspection of the inner cannula may be necessary.(Floyd B., 2011).

Regarding to sociodemographic characteristics of nurses, the current study included 30 nurses.Slightly more than three quarters of the studied nurses were aged from 20 to less than 30 years and halfof them were technical nurse. According to their years of experience it was found that more than one thirds of them had experience less than five years. These results goes in the same line with Sobeh, (2010) who found that the majority of the studied nurses working in all governmental intensive care units at port-said hospitals had more than 4 years of experience; their age was between 20 to 30 years.

Regarding to the studied nurses' education, the present study results revealed that half of nurses were technical nurse; these results disagree with Ally, (2012) and Mosazade Sari et al., (2014) report that more than two third of nurses had diploma.

From the researcher point of view, these findings could be because of changing the education system from diploma (3 yrs system) to technical institute (5yrs system), thus, nurses graduate in twenty of their age.

Regarding to the nurses` general knowledge about tracheostomy care, it was found that more than three fifth of nurses had satisfied level of knowledge about tracheostomy care, its characteristics and suction from tracheostomy tube. These results are in accordance with the finding of Parson and Morris, (2010) who showed that the knowledge of nurses in the sub areas of tracheostomy care ranged from 96.6 to 100 percentages except in the area of saline instillation, were 46.7 percent only.

The present study also enumerate that more than two third of nurses had satisfied level of practice about both tracheostomy care and tracheostomy suction. Therefore, there were more than two third of nurses had satisfied level of total practice. From the researcher point of view these results might be due to good monitoring, observation, technical training of old, experienced nurses and the head nurse.

Regarding to Patient' socio-demographic data, it was found that more than half of patients age were less 35years from male gender, and was married. These results are in accordance with the finding of Nyansikera, (2012) more than two third of the respondents were married and from male.

This result disagreements with Tseng et al, (2015) who carried out a study inChia Nan University of Pharmacy \& Science, Tainan, Taiwan asserted that the mean age of all patients was 69.5 years, and more than half of them were male and were 
married.While reported that, "The average age for all patients was 47 years with males".

Regarding to correlations between total nurses' knowledge and total nurses' practice there was a statistically significant positive correlation between total nurses' knowledge and total nurses' practice; it might be related to lack of training programs. So, from the researcher point of view, the hospital should concern of providing continuous training for intensive care unit nurses to gain and update their knowledge and practice as such, they are critical to the provision of quality care. On the other hands, Nyansikera, (2012) necessitated on that lack of enough training in tracheostomy care, is a huge contributor to morbidity and mortality of the patients.

\section{CONCLUSION:}

The most common cause of performing tracheostomy needed artificial ventilation more than 15 days. In addition most of the studied nurses had satisfactory level of knowledge and practice regarding providing care to tracheostomy patient. finally there was positive statistically significant relation between nurse's knowledge, and practice.

\section{RECOMMENDATIONS:}

- Developing a system of periodical nurses' evaluation to determine strategies of upgrading their knowledge and enhancing their practice regarding tracheostomy care.

- Developing specific procedure booklet (standard of care) about caring of tracheostomy patients.

- Close supervision and monitoring is needed to ensure the quality care is provided by nurses while applying tracheostomy care and suctioning.

- Strict applications of aseptic techniques and infection control precautions are strongly recommended in order to prevent many of the complications associated with tracheostomy tube.

\section{REFERENCES:}

Ali A., (2013): Assessment of nurses' knowledge and practice regarding care of patient with endotracheal tube. Unpublished master thesis, faculty of nursing, Ismailia University.Appendix II.

Ally T. S., (2012): knowledge and practice of intensive care nurses on prevention of ventilator associated pneumonia at Muhimbil National HospitalDaressalaam, a national perspective. Laryngoscope, 122 :(61). 46-50. 


\section{American Association of Respiratory Care $(A A R C)$ clinical practice guideline,} (2010): endotracheal suctioning of mechanically ventilated patients with artificial airways. Respir Care. 55: (6). 758-64.

Bhandary $R$. and Niranjan N., (2011): Tracheostomy. Anesthesia tutorial of the week. 241:1-12. ATOTW weekly -

Floyd B., (2011): Tracheostomy care. An Evidence-based Guide to Suctioning and Dressing Changes. American Nurse Today 7: (6),9-11.

Frcpch K. ,Fdsrcs I., andFreeth H.,(2014): On the Right Trach? A review of the care received by patients who underwent a tracheostomy. A report by the National Confidential Enquiry into Patient Outcome and Death . 12.

Glendon A., Hyde b., Stephanie A., Savage A., Ben L., Zarzaur c., Jensen E., and Hart-Hyde A.,(2015) : Early tracheostomy in trauma patients saves time and money. Injury, Int. J. Care Injured 46 (19)..110-114.

McGrath B., and Thomas N., (2011): Patient safety incidents associated with tracheostomies occurring in hospital wards: a review of reports to the UK National Patient Safety Agency. Post graduate Med J; 12: (86), 522-525.

Mosazade Z., Maleki M., Atashzade S., andMehrabi Y.,(2013): The Study of the observance status of tracheostomy standard principles by nurses in selected teaching hospitals in Tehran. Bull. Env. Pharmacol. Life Sci., 3: (12). 12-17.

National Confidential Enquiry into Patient Outcome and Death (NCEPOD), (2014): On the Right Trach? A Review of the Care Received by Patients who underwent a Tracheostomy. 12-18.

Nemati S., Banan R., Bakhshi F., KazemN.,andTaravat H., (2013): The study of the way of doing cares after tracheostomy in Rasht's hospitals. The magazine of Gilan Medical Sciences University. 22: (86). 32-39.

Nora H., Cheung M., Lena M., and Napolitano M., (2014):tracheostomy; timing; percutaneous dilatational; open; outcomes; complications. Respir Care j. 59: (6). 895919.

Nyansikera E., (2012): Quality of tracheostomy care: a case of Kenyatta National hospital, Nairobi county, Published master thesis in November 2013 at DC.IdentifierURI, 44- 45. 
Parson J., and Morris L., (2010): Rehabilitation and recovery. In: Morris LL, Afifi MS, eds. Tracheostomies: The Complete Guide. New York, NY: Springer Publishing Science to Life, $3^{\text {rd }}$ ed. Wiley: New Jersey. Pp. 684-691.

Ramont R. and Niedringhaufd., (2011): fundamental nursing care. $2^{\text {nd }}$ Ad., London. 775-780

Shah R., Lander L, Berry G., Nussenbaum B., Merati A., and Roberson DW. , (2011): Tracheotomy outcomes and complications: A National perspective. The Laryngoscope, 122:(22), 25-29.

Tseng K., Shieh J., Cheng K., and Chiang Sh., (2015): Tracheostomy versus Endotracheal Intubation Prior to Admission to a Respiratory Care Center: A Retrospective Analysis. International Journal of Gerontology. 9 :( 22).151-155. 


\section{جودة الرعاية|التمريضية على مريض الثق الحنجري}

أ.م.د/ شيرين احمد قلاوةـ أ.م.د/ عادل الهادى دياب - م/سامية الجزار - هالة مسعد الغواب

\section{الخلاصة}

مقدمة: تعتبر عمليه الثق الحنجري هي عباره عن فتحه جر احيه على سطح الجلد المؤدى الى القصبة الهوائية ، وتجرى هذه الجر احة في حالات وجود انسداد فى مجرى الهو اء العلوى و الناتج عن تورم يسببه الحرق ،او الحساسية|الففرطة ، او الصدمات او العدوى ،كما أنها ضرورية للحالات التي تحتاج للتنفس الصناعي لفتره طويله ، وكما أنها تحمى مجرى الهو اء فى حالات إفرازات القصبةالهو ائية|لمفرطةو التي تتطلب عمل تثفيط منتظم ، و أيضا تعتبر هذه الجر احة جزء من الاجر اءات الجر احية الاخرى مثل جر احات الر أس و الرقبة. الهلف من اللراسة: تهدف الدر اسة الى تحديدجودة الر عاية التمريضية لمريض الثق الحنجري .تصميم البحث :سوف يتم استخدام دراسة وصفية لتحقيق الهدف من هذه الدر اسة. مكان البحث: هذه الدر اسة سيتم تنفيذها في وحده العناية المركزة في مستشفى جامعة الأز هر بعينه البحث:جميع الممرضات العاملين (30ممرضه) في الأماكن السابق ذكر ها. وجميع المرضى الذين سيتم حجز هم في الأماكن السابق ذكر ها خلال سته أشهر( 50مريض). نتائج الدراسة: اكثر من ثلاث ارباع التمريض يبلغ عمر هم من 20 الى 30 سنه.اكثر من ثلتي ممرضات الدر اسة لديهم معلومات وممارسات كافية عن انبوبه الثق الحنجري وخصائصها وكيفيه العناية بها.أكثر من نصف المرضى الذين نم اجر اء عمليه الثق الحنجري لهم بسبب اتصالهم بجهاز التنفس الصناعي لمده تزيد عن اسبو عين ( 15يوم).الخلاصة: هناك علاقه ذات دلاله إحصاءيه بين معلومات التمريض وممارساتهم التمريضية. هناك علاقه ايجابيه ذات دلاله إحصائية بين معلومات التمريض وممارساتهم ـ التوصيات:توصي الدر اسة بتطوير نظام لتقييم المرضات لتحديد استر اتيجيات رفع مستوى معلوماتهم وتعزيز ممارساتهم التمريضية وتتجيع الممرضات لحضور المؤتمر ات المحلية والدولية و الحلقات الدر اسية والندوات ورشة العمل ودر اسة تأثير هذه البرامج علىحوده الرعاية التمريضية لمريض الثق الحنجري. 